\title{
Feature
}

\section{From the National Academies: Ongoing Challenges to Evolution Education: Resources and Activities of the National Academies}

\author{
Jay B. Labov \\ National Academy of Sciences, Center for Education, Washington, DC 20001
}

\section{INTRODUCTION}

As I sat down to write this column, I noticed in my e-mail inbox today's daily Lexis/Nexis search that I have requested for articles on challenges to the teaching of evolution or attempts to introduce "alternative views" such as intelligent design into science courses. Today's entry included 25 articles, op-eds, letters to editors, transcripts of network and cable news shows, and a note that an additional 24 articles were not displayed. All in all, a slow news day on this topic compared with searches that have yielded at least twice that number of hits per day in the past week or two.

One piece of good news that these issues are finally receiving much needed, serious, and long overdue attention from a much broader spectrum of the scientific community. Scientists, both individually and collectively, and professional organizations from across the scientific disciplines are also recognizing these challenges to evolution as symptomatic of assaults on science and science education writ large.

After all, Gallup and other polls have shown repeatedly that, for at least the past four decades during which this information has been collected, the percentage of people in the United States who indicate that creationism (now subsumed by the broader intelligent design movement) should be taught alongside with or instead of evolution in public school science classes has not changed (e.g., Newport, 2004; CBS News Polls, 2004; Pew Research Center, 2005). A growing body of education research also suggests that students at all grade levels ( $\mathrm{K}-12$ and postsecondary) come to science courses with misconceptions about evolution that are very difficult to correct or dislodge (e.g., Bishop and Anderson, 1990; Greene, 1990; Settlage, 1994; Anderson et al., 2002; Tanner and Allen, 2005).

The problem of misconceptions about science is not unique to evolution, of course, but in the case of evolution, the problem is compounded because many students have been told that their personal belief systems will be challenged or undermined by engaging in learning about this subject. This concern underlies the angst and anger that some parents, members of school boards, and state legislators express when students are not exposed to purported "controversies" or "weaknesses" in the theory of evolution that are being touted by the Discovery Institute (the leading organization

DOI: $10.1187 /$ cbe.05-08-0111

Address correspondence to: Jay B. Labov (jlabov@nas.edu). promoting intelligent design). In response to this worry, they are taking a variety of actions in increasing numbers of school districts and states to change the ways that evolution is taught (see Coyne, 2005; Orr, 2005; and the Web site of the National Center for Science Education - http://ncseweb.org ${ }^{1}$ - for overviews and resources).

Currently there is little consensus within the scientific community about how to confront these challenges effectively. Responses by scientific societies and others are typically reactive to the latest provocation rather than proactive. Individual scientists and professional societies publish a litany of position papers decrying every new challenge, $^{2}$ but rarely are there collective, coordinated statements from scientific organizations. ${ }^{3}$ In contrast, messages from proponents of intelligent design present a unified front, are clear and simple to remember (for example, "Teach the Controversy"), and resonate with a large number of people (e.g., Wilgoren, 2005).

However, the situation is beginning to change as scientific organizations realize that providing the public with easy-tounderstand information and direct messages is critically important. The remainder of this column describes the steps we at the National Academies have taken since our last

\footnotetext{
${ }^{1}$ All urls cited in this article were last checked for operability on August 25, 2005.

${ }^{2}$ See, for example, individual statements of some 68 scientific and scholarly organizations from around the world (http://www.ncseweb.org/resources/articles/9522_statements_from_ scientific_and_12_19_2002.asp) and from 36 education organizations (http://www.ncseweb.org/resources/articles/3213_ statements_from_educational_or_8_8_2003.asp) on teaching of evolution.

${ }^{3}$ For two examples of joint statements from the leadership of the National Research Council, American Association for the Advancement of Science, and National Science Teachers Association to the Kansas State Board of Education in 1999 and 2001, see http://www4.nationalacademies.org/news.nsf/isbn/ s09231999?OpenDocument and http://www.nasonline.org/site/ PageServer?pagename=NEWS_statement_president_02142001_BA_ science_education, respectively. Also, a statement, "Intelligent Design not supported by science," was co-signed by more than 120 members of the Iowa State University faculty (both scientists and nonscientists) and published in the student newspaper (Schuman, 2005).
} 
article to address this issue (Alberts and Labov, 2004) and what we are planning for the future, both as an organization and in collaboration with other scientific organizations.

\section{RECENT AND PLANNED ACTIVITIES WITHIN THE NATIONAL ACADEMY OF SCIENCES}

\section{Web Site}

For many years the National Academy of Sciences (NAS) has made its institutional statements, publications, and other resources on evolution and evolution education available to the public. However, until recently, these items were scattered across the Web site and sometimes difficult to locate. To remedy this problem, there is now an evolution Web page (http://nationalacademies.org/evolution) with links to the Academies' resources on evolution education and to other resources.

\section{Publications for Teachers and the General Public}

The NAS has published three reports to help science teachers and the general public better understand the principles of evolution, the evidence that supports these principles, and the basis for the controversies that surround evolution education. They include Teaching About Evolution and the Nature of Science (NAS, 1998); Science and Creationism: A View from the National Academy of Sciences, 2nd ed. (NAS, 1999); and Evolution in Hawaii: A Supplement to Teaching About Evolution and the Nature of Science (2004). Until several months ago, all of these publications were available to read online without charge but could only be downloaded one page at a time. All three of these reports are now freely downloadable as individual pdf files. They can be accessed from the evolution Web site described above. During the past year the Academies also worked with several professional organizations for teachers to make available a free CD-ROM containing all three of these reports; more than 1,500 teachers took advantage of the offer.

Standards for teaching science in grades $\mathrm{K}-12$ across the country are based in part on the curricular and content recommendations in the National Research Council's (NRC) National Science Education Standards (1996). The Standards also articulate clear guidelines about what students should know and be able to do to demonstrate an understanding of evolution. This publication is also now freely downloadable and can be accessed through the URL provided below or through a link on the Academies' evolution Web site.

The current edition of Science and Creationism was prepared when the intelligent design movement was nascent and therefore devotes fewer than two paragraphs of text to this topic. An authoring committee is now revising and updating the report. The updated publication is expected to provide much more information about the concept of intelligent design and the reasons why the vast majority of

\footnotetext{
${ }^{4}$ The Joseph Henry Press (JHP), an imprint of the National Academies Press, was created with the goal of publishing well-crafted, authoritative books on science, technology, and health for the science-interested general public. JHP books represent a broad range of topics, from modern physics and frontiers of medicine to scientific biography and early childhood development. More information is available at http:// www.jhpress.org/.
}

the scientific community does not consider it to be a scientific theory. As with its predecessor, the revised version will be available for free downloading as a pdf file from both the National Academies Press and from our evolution Web site.

In September 2005, the Joseph Henry Press ${ }^{4}$ released Genesis: The Scientific Quest for Life's Origins. The book is authored by Robert Hazen, a geophysicist at the Carnegie Institution of Washington, and provides information on current theories of life's origins and the evidence supporting these ideas.

\section{Public Events}

The Marian Koshland Science Museum of the NAS ${ }^{5}$ will sponsor several lectures on issues surrounding evolution. For example, Dr. Hazen gave a public lecture on his book in September 2005. The Museum's Advisory Board is also currently looking at the design of the next exhibit, which will focus on infectious diseases; presentations of evolutionary principles (for example, the emergence of drugresistant microbes) will likely constitute an important part of that exhibit.

\section{National Academies Summer Institute for Education in the Life Sciences}

One goal of the Summer Institutes ${ }^{6}$ has been for participants to develop "teachable units," a combination of classroom, laboratory, and field experiences, along with assignments and assessments of topics that faculty find difficult to teach and students often have problems learning well. The teachable units are intended for sections of introductory biology courses taught to large numbers of students.

One of the teachable units developed each year has focused on evolution. The teams that produced these units are actively working to implement the units in their classes. Once these units are class-tested, evaluated, and revised, they will be made available to the larger life sciences community on the Summer Institutes Web site.

\section{Development of an NRC Study on the Benefits of Understanding Evolution}

In November 2004, the American Institute of Biological Sciences and the National Association of Biology Teachers (NABT) cosponsored a major symposium, Evolutionary Science and Society: Educating a New Generation, during the NABT annual meeting in Chicago. ${ }^{7}$ One section of that event featured several presentations on how knowledge

\footnotetext{
${ }^{5}$ For additional information about the Marian Koshland Science Museum, see Labov (2004) or http://www.koshland-sciencemuseum.org/.

${ }^{6}$ General descriptions of the National Academies Summer Institute are available in Wood and Gentile, 2003; Wood and Handelsman, 2004; Labov, 2005. The Summer Institutes have been actively supported by the Howard Hughes Medical Institute and the National Academies and hosted annually since their inception on the campus of the University of Wisconsin, Madison. The Web site for the Institutes is http:// academiessummerinstitute.org/.
}

${ }^{7}$ Additional information about this symposium is available at http://www.aibs.org/special-symposia/2004.html. 
of evolution is being used in fields such as agriculture, biotechnology, forensics, medicine, and public health. The Biological Sciences Curriculum Study is producing a volume to discuss the educational aspects of these presentations. The NRC's Board on Life Sciences is looking into the feasibility of a study that would focus on the application of evolutionary theory to current-day research in the life sciences as well as areas in the physical, chemical, earth, and behavioral sciences. This study would discuss the various ways in which ongoing research in a variety of fields is dependent on understanding evolution.

\section{COLLABORATIVE ACTIVITIES WITH OTHER ORGANIZATIONS}

\section{Cosponsored Events at the 2006 Annual Meeting of AAAS}

The NAS, NABT, and the Society for Developmental Biology together will serve as co-organizers for three events to be held during the February 2006 annual meeting of the American Association for the Advancement of Science (AAAS) in St. Louis. These sessions will call attention to current threats to the teaching of science, with a focus on the present controversies surrounding the teaching of evolution. Some 15 other scientific societies already have agreed to cosponsor these events. A 90-minute symposium will examine threats to evolution education from the perspectives of several disciplines and of a high school biology teacher from Kansas. A 3-hour workshop will bring together individual scientists and representatives from scientific organizations to explore new ways to work collaboratively to confront these challenges. In addition, Donald Kennedy, editor of Science, will present a topical lecture on this subject.

\section{Work with Other Organizations}

We are also working with a consortium of professional societies in the life, chemical, physical, earth, and behavioral and social sciences (all having headquarters in the Washington, DC area) that have agreed that there must be closer coordination of efforts on these issues. The new consortium has met once at AAAS headquarters and is planning another meeting for Fall 2005. Immediate goals include drafting a unified position paper about the teaching and learning of evolution. We also will discuss possible longer-term collaborative efforts on aspects that transcend individual scientific disciplines.

As described by Alberts and Labov (2004), the NAS also continues to work with local organizations in a number of states that are at the forefront in confronting challenges to the teaching of evolution and the inclusion of intelligent design in science classrooms.

Some members of the NAS and I also have spent considerable time speaking with print and broadcast journalists from the United States and around the world about these issues. For example, interviews have been given to broadcast reporters from Radio Canada Quebec, German Public Radio, Public Broadcasting, and a CBS radio affiliate in Washington, DC. The Academies' Office of News and Public Information also sends information almost daily to journalists or directs them to authoritative scientific sources both within and outside the National Academies about evolution issues.

\section{Legal Proceedings}

The NAS is a cosponsor (along with some 55 other scientific societies) of an amicus curiae brief ${ }^{8}$ for the appeal of Selman vs. Cobb County, GA Board of Education. This case involves the placing of stickers in high school textbooks stating that "evolution is a theory, not a fact." In September 2004 a federal judge ordered the stickers removed from textbooks, and the school board has appealed. The case is expected to be heard in the 11th Circuit Court of Appeals in Fall 2005. Definitions of terms that appear in the amicus brief, such as "science," "fact," and "theory," as employed by the scientific community, are based on the NAS' Science and Creationism report, which was instrumental in helping to refine the language of the brief.

\section{A PERSONAL NOTE}

In an earlier CBE column (Alberts and Labov, 2004), Bruce Alberts and I made the following point:

\begin{abstract}
As scientists, we also should make it our responsibility to present the evidence for biological evolution to all of our students, especially in introductory courses. Most students who enroll in our introductory courses will use them as their terminal courses in science. At least some of those students will go on to careers as teachers or as public servants who will be asked to make decisions about whether to allow nonscientific approaches to teaching evolution to appear in science curricula. It is our responsibility to equip them with the knowledge and understanding of science that they will need to confront such challenges.
\end{abstract}

During the past year I have spoken with and listened to college science faculty at number of conferences, as well as during the 2005 National Academies Summer Institute, about ways they might help to counteract these disturbing trends. I am more convinced than ever that we must rethink the ways in which evolution is presented in our courses, especially in introductory courses. Is evolution taught as a disconnected unit, or does it truly serve as a foundation for all aspects of a biology course? If taught as a unit, are explicit connections made to other topics in the course, and vice versa? Does the course or unit stress both recent evidence for evolution as well as paleontological and phylogenetic evidence? Do students see that evolutionary science is a vital, ongoing component of modern biological research?

I also am convinced that we as educators must think much more carefully and seriously about how we can help our students learn about and appreciate both the processes and the nature of science. I contend that these topics must be addressed in all science courses, but especially at the introductory level. These topics need to be viewed as essential components of course content.

For example, many students fail to understand how scientists can make proclamations about speciation or about how life began on this planet because no human being has ever observed these events. However, those same students

${ }^{8}$ The text for this amicus, including the list of sponsors, is available at http://www.ncseweb.org/selman/SelmanScientistsBrief final.pdf, 
have few problems accepting that forensic scientists can solve crimes committed many years ago that nobody (besides the perpetrators) witnessed, using the processes and tools of modern science. How can we build on what students already know to help them understand that science has the power to address similar questions about evolution?

And can we also help students better appreciate that some issues are beyond the realm and reach of science? Too often, opportunists pit science against religious belief, as if these are at opposite ends of some continuum. If we can help our students understand that, by its very nature, science is incapable of addressing theological questions, we may begin to defuse these bitter debates.

\section{ACKNOWLEDGMENTS}

I thank my National Academies colleagues Maureen O'Leary, Adam Fagen, and Frances Sharples for reviewing and offering comments on an earlier draft of this manuscript.

\section{REFERENCES}

Alberts, B., and Labov, J.B. (2004). From the National Academies: teaching the science of evolution. Cell Biol. Educ. 3, 75-80. http:// cellbioed.org/article.cfm?ArticleID=98.

Anderson, D.L., Fisher, K.M., and Norman, G.J. (2002). Development and evaluation of the conceptual inventory of natural selection. J. Res. Sci. Teach. 39(10), 952-978.

Bishop, B.A., and Anderson, C.W. (1990). Student conceptions of natural selection and its role in evolution. J. Res. Sci. Teach. 27(5), 415-427.

CBS News Polls (2004). Creationism trumps evolution. New York: CBS News. http://www.cbsnews.com/stories/2004/11/22/opinion/ polls/main657083.shtml.

Coyne, J. (2005). The case against intelligent design: the faith that dare not speak its name. The New Republic Online, issued August 22, 2005. http://www.tnr.com/docprint.mhtml?i=20050822\&s=coyne082205.

Greene, E.D. Jr. (1990). The logic of university students' misunderstanding of natural selection. J. Res. Sci. Teach. 27(9), 875-885.

Hazen, R.M. (2005). Genesis: The Scientific Quest for Life's Origins. Washington, DC: Joseph Henry Press. http://www.nap.edu/catalog/ 10753.html.

Labov, J.B. (2004). From the National Academies. Cell Biol. Educ. 3, 8-10. http://cellbioed.org/article.cfm?ArticleID=87.

Labov, J.B. (2005). From The National Academies: a tribute to the science education legacy of National Academy of Sciences president
Bruce Alberts. Cell Biol. Educ. 4, 185-188. http://cellbioed.org/ article.cfm?ArticleID=154.

National Academy of Sciences (1998). Teaching About Evolution and the Nature of Science. Washington, DC: National Academies Press. http://nap.edu/catalog/5787.html.

National Academy of Sciences (1999). Science and Creationism: A View from the National Academy of Sciences, 2nd ed. Washington, DC: National Academies Press. http://www.nap.edu/catalog/6024. html.

National Academy of Sciences (2004). Evolution in Hawaii: A Supplement to Teaching About Evolution and the Nature of Science. Washington, DC: National Academies Press. http://books.nap.edu/ catalog/10865.html.

National Research Council (1996). National Science Education Standards. Washington, DC: National Academies Press. http://nap. edu/catalog/4962.html

Newport, F. (2004). Third of Americans say evidence has supported Darwin's evolution theory. The Gallop Organization. http://www. gallup.com/poll/content/login.aspx?ci=14107.

Orr, H.A. (2005). Master plan: Why intelligent design isn't. New Yorker, May 30, 2005. http://www.newyorker.com/fact/content/ articles/050530fa_fact.

Pew Research Center for the People and the Press (2005). Religion a strength and weakness for both parties: public divided on origins of life. Washington, DC. http://people-press.org/reports/display. php3?Report10=254.

Schuman, J. (2005). 120 Professors at Iowa State U. sign statement criticizing intelligent-design theory. Chronicle of Higher Education Daily, August 25, 2005. http://chronicle.com/daily/2005/08/ 2005082605n.htm.

Settlage, J. Jr. (1994). Conceptions of natural selection: a snapshot of the sense-making process. J. Res. Sci. Teach. 31(5), 449-457.

Tanner, K., and Allen, D. (2005). Approaches to biology teaching and learning: understanding the wrong answers - teaching toward conceptual change. Cell Biol. Educ. 4, 112-117. http://cellbioed.org/ article.cfm?ArticleID=145.

Wilgoren, J. (2005). Politicized scholars put evolution on the defensive. New York Times, August 21, 2005. http://www.nytimes. com/2005/08/21/national/21evolve.html.

Wood, W., and Gentile, J. (2003). Meeting report: the first National Academies Summer Institute for Undergraduate Education in Biology. Cell Biol. Educ. 2, 207-209. http://cellbioed.org/article. $\mathrm{cfm}$ ?ArticleID $=74$.

Wood, W.B., and Handelsman, J. 2004. Meeting report: the 2004 National Academies Summer Institute on Undergraduate Education in Biology. Cell Biol. Educ. 3, 215-217. http://cellbioed.org/article. cfm?ArticleID=121. 